\title{
Direct production of organic acids from starch by cell surface-engineered Corynebacterium glutamicum in anaerobic conditions
}

\author{
Yota Tsuge ${ }^{1}$, Toshihiro Tateno ${ }^{2}$, Kengo Sasaki ${ }^{1}$, Tomohisa Hasunuma ${ }^{1}$, Tsutomu Tanaka ${ }^{2}$ and Akihiko Kondo ${ }^{2,3,4^{*}}$
}

\begin{abstract}
We produced organic acids, including lactate and succinate, directly from soluble starch under anaerobic conditions using high cell-density cultures of Corynebacterium glutamicum displaying a-amylase (AmyA) from Streptococcus bovis 148 on the cell surface. Notably, reactions performed under anaerobic conditions at 35 and $40^{\circ} \mathrm{C}$, which are higher than the optimal growth temperature of $30^{\circ} \mathrm{C}$, showed $32 \%$ and $19 \%$, respectively, higher productivity of the organic acids lactate, succinate, and acetate compared to that at $30^{\circ} \mathrm{C}$. However, a-amylase was not stably anchored and released into the medium from the cell surface during reactions at these higher temperatures, as demonstrated by the $61 \%$ and $85 \%$ decreases in activity, respectively, from baseline, compared to the only $8 \%$ decrease at $30^{\circ} \mathrm{C}$. The AmyA-displaying C. glutamicum cells retained their starch-degrading capacity during five $10 \mathrm{~h}$ reaction cycles at $30^{\circ} \mathrm{C}$, producing $107.8 \mathrm{~g} / \mathrm{l}$ of total organic acids, including $88.9 \mathrm{~g} / \mathrm{l}$ lactate and $14.0 \mathrm{~g} / \mathrm{l}$ succinate. The applicability of cell surface-engineering technology for the production of organic acids from biomass by high cell-density cultures of C. glutamicum under anaerobic conditions was demonstrated.
\end{abstract}

Keywords: Corynebacterium glutamicum; Organic acid; a-amylase; Cell-surface engineering

\section{Introduction}

In the new era of green chemistry, the utilization of renewable resources, such as plant biomass, and environmentally friendly chemical products are eagerly desired. In particular, the organic acids lactic and succinic acids are recognized as ideal candidates for the building blocks of next-generation plastics. Both compounds were selected within the top 30 value-added chemicals manufactured from biomass by the U.S. Department of Energy (Werpy et al. 2004).

Corynebacterium glutamicum is a Gram-positive bacterium with a high $\mathrm{G}+\mathrm{C}$ content and has been widely used in industry for the large-scale production of amino acids, including glutamate and lysine (Nakayama et al. 1961; Kinoshita 1985). Recently, C. glutamicum was shown to have increased metabolic flow through the glycolytic pathway and reductive branch of the tricarboxylic acid (TCA)

\footnotetext{
* Correspondence: akondo@kobe-u.ac.jp

${ }^{2}$ Department of Chemical Science and Engineering, Graduate School of Engineering, Kobe University, 1-1 Rokkodai, Nada, Kobe 657-8501, Japan ${ }^{3}$ Biomass Engineering Program, RIKEN, 1-7-22 Suehiro-cho, Tsurumi-ku, Yokohama, Kanagawa 230-0045, Japan

Full list of author information is available at the end of the article
}

cycle under oxygen-deprived conditions, resulting in the exclusive production of the organic acids lactate, succinate, and acetate (Inui et al. 2004). High cell-density cultivation promoted the consumption of oxygen and obviated the need for the removal of oxygen. Using this system, in which resting cell of C. glutamicum were cultured at high cell-density under anaerobic conditions, several organic acids, including lactate and succinate, were produced at high levels (Okino et al. 2005, Okino et al. 2008a, Okino et al. 2008b, Litsanov et al. 2012, Tsuge et al. 2013).

The cell-surface display of heterologous proteins has several potential biotechnological applications, including adsorption or degradation of environmental pollutants, recovery of rare metal ions, biosensors, and recombinant protein production (Kuroda and Ueda 2010, 2011). In addition to these applications, yeast and bacteria displaying fusion proteins composed of a cell surface-anchoring protein and a biomass-degrading protein have been effectively used for the fermentation of biomass resources, such as starch, xylan, cellobiose, and cellulose (Katahira et al. 2004; Matano et al. 2012; Murai et al. 1997; Narita et al. 2006; Yamada et al. 2013). The main advantage of 
cell surface-engineering technology is that cells displaying useful proteins can be reutilized multiple times, similar to biocatalysts (Matano et al. 2013; Yamakawa et al. 2012). We previously developed a cell surface-display system in C. glutamicum using the Bacillus subtilis PgsA and C. glutamicum PorC proteins as anchors for displaying $\alpha$ amylase from Streptococcus bovis 148 and $\beta$-glucosidase from Saccharophagus degradans 2-40 for lysine production from starch and cellobiose, respectively, under growing conditions (Tateno et al. 2007a; Adachi et al. 2013). Although it was anticipated that the co-utilization of cell surface-engineering technology zand high cell-density systems would improve organic acid production from biomass, the efficacy of this combined approach in C. glutamicum has not been demonstrated.

In the present study, we demonstrated the application of cell surface-engineering technology for the production of organic acids by $C$. glutamicum cells cultured at high-density under anaerobic conditions in a minimal salts medium. Using this approach, organic acids, including lactate and succinate, were produced directly from starch by C. glutamicum displaying $\alpha$-amylase on the cell surface. Moreover, we reutilized the C. glutamicum cells for the repeated production of organic acids to evaluate the stability and durability of the cell-surface displayed protein in C. glutamicum.

\section{Materials and methods}

Bacterial strains, media, growth conditions, and plasmids All bacterial strains and plasmids used in this study are listed in Table 1. Escherichia coli NovaBlue was used for the construction of plasmids. E. coli SCS110 was used for the preparation of plasmid DNA for the transformation of C. glutamicum. C. glutamicum ATCC13032 was used as a host strain. E. coli strains were grown at $37^{\circ} \mathrm{C}$ in Luria-Bertani (LB) medium (Sambrook et al. 1989), and C. glutamicum and its recombinants were grown at $30^{\circ} \mathrm{C}$ in $\mathrm{A}+$ medium ( $5 \mathrm{~g}$ yeast extract, $5 \mathrm{~g}$ casamino acids, $4 \mathrm{~g}$ urea, 14 $\mathrm{g}$ ammonium sulfate, $0.5 \mathrm{~g} \mathrm{KH}_{2} \mathrm{PO}_{4}, 0.5 \mathrm{~g}$ $\mathrm{K}_{2} \mathrm{HPO}_{4}, 0.5 \mathrm{~g} \mathrm{MgSO}_{4} \cdot 7 \mathrm{H}_{2} \mathrm{O}, 20 \mathrm{mg} \mathrm{FeSO}{ }_{4} \cdot 7 \mathrm{H}_{2} \mathrm{O}, 20 \mathrm{mg}$ $\mathrm{Mn}_{2} \mathrm{SO}_{4} \cdot \mathrm{H}_{2} \mathrm{O}, 0.2 \mathrm{mg}$ biotin, and $0.2 \mathrm{mg}$ thiamine per liter) supplemented with $2 \%$ glucose. When required, kanamycin was added at a concentration of $50 \mu \mathrm{g} / \mathrm{ml}$ for $E$. coli and at $25 \mu \mathrm{g} / \mathrm{ml}$ for C. glutamicum.

\section{Plasmid construction}

All polymerase chain reactions (PCR) were performed using KOD-Plus-DNA polymerase (Toyobo Co., Ltd., Osaka, Japan). The pgsA gene was amplified by PCR using the plasmid pHLA (Narita et al. 2006) as template with primers BamHI-pgsA_F and pgsA-SacI_R (Table 1). The amplified fragment was digested with BamHI and SacI, and then ligated into BamHI/SacI digested plasmid pCC (Tateno et al. 2007b). The resulting plasmid was designated pCC$p g s A$. The $\alpha$-amylase gene (amyA) from Streptococcus bovis 148 was amplified by PCR using pCCS-amyA (Tateno et al. 2007b) as template and primers SacI-amyA_F and amyAXhoI_R (Table 1). The amplified fragment was digested with $S a c I$ and XhoI, and was then ligated into $S a c I / X h o I$ digested $\mathrm{pCC}-p g s A$. The resulting plasmid was designated pCC-pgsA-amyA.

Table 1 Strains, plasmids, and primers used in this study

\begin{tabular}{|c|c|c|}
\hline $\begin{array}{l}\text { Strain, plasmid or } \\
\text { primer }\end{array}$ & Relevant genotype or description & $\begin{array}{l}\text { Reference or } \\
\text { source }\end{array}$ \\
\hline \multicolumn{3}{|l|}{ Strains } \\
\hline \multicolumn{3}{|l|}{ E. coli } \\
\hline NovaBlue & 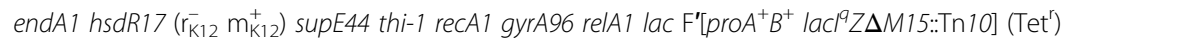 & Merck \\
\hline SCS110 & 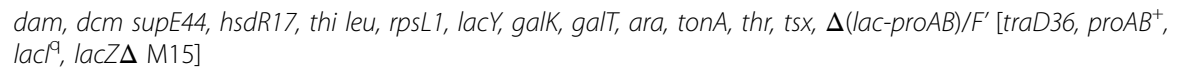 & Stratagene \\
\hline \multicolumn{3}{|l|}{ C. glutamicum } \\
\hline ATCC13032 & Wild-type strain & ATCC \\
\hline \multicolumn{3}{|l|}{ Plasmids } \\
\hline $\mathrm{pCC}$ & $\mathrm{Km}^{r}$; E. coli-C. glutamicum shuttle vector containing cspB promoter & $\begin{array}{l}\text { Tateno et al. } \\
2007 \mathrm{~b}\end{array}$ \\
\hline pCC-pgsA & $\mathrm{Km}^{\mathrm{r}}$; pCC carrying pgsA & This study \\
\hline pCC-pgsA-amyA & $\mathrm{Km}^{\mathrm{r}}$; pCC-pgsA carrying amyA gene fused with $3^{\prime}$ terminal of pgsA & This study \\
\hline \multicolumn{3}{|l|}{ Primers } \\
\hline BamHI-pgsA_F & CGCGGATCCATGAAAAAAGAACTGAGCTTTCAT & This study \\
\hline pgsA-Sacl_R & ACGCGTCGACTTACTTGTCATCGTCATCCTTGTAGTCGAGCTC TTTAGATTTAGTT TGTCACTATGATC & This study \\
\hline Sacl-amyA_F & CCCGAGCTCGATGAACAAGTGTCAATGAAAGAT & This study \\
\hline amyA-Xhol_R & CCGCTCGAGTTATTTIAGCCCATCTTTATTATAGTTT & This study \\
\hline
\end{tabular}




\section{DNA manipulations}

Transformation of $E$. coli was performed by the $\mathrm{CaCl}_{2}$ method. Transformation of C. glutamicum was carried out as described previously (Tateno et al. 2007a).

\section{Bioprocess conditions for organic acid production}

For organic acid production, cells were harvested from $500 \mathrm{ml}$ cultures in A+ medium by centrifugation $(5000 \times \mathrm{g}$, $4^{\circ} \mathrm{C}$ for $10 \mathrm{~min}$ ) after $16 \mathrm{~h}$ cultivation at $30^{\circ} \mathrm{C}$ with starting at an optical density at $600 \mathrm{~nm}\left(\mathrm{OD}_{600}\right)$ of 0.05 . The cell pellet was resuspended in $40 \mathrm{ml} \mathrm{K10}$ medium, which consisted of $168 \mathrm{mg} \mathrm{NH}_{4} \mathrm{H}_{2} \mathrm{PO}_{4}, 151 \mathrm{mg}\left(\mathrm{NH}_{4}\right)_{2} \mathrm{HPO}_{4}, 250 \mathrm{mg}$ $\mathrm{KCl}, 400 \mathrm{mg} \mathrm{MgSO}_{4} \cdot 7 \mathrm{H}_{2} \mathrm{O}, 16 \mathrm{mg} \mathrm{FeSO}_{4} \cdot 7 \mathrm{H}_{2} \mathrm{O}, 16 \mathrm{mg}$ $\mathrm{MnSO}_{4} \cdot 7 \mathrm{H}_{2} \mathrm{O}, 0.16 \mathrm{mg}$ biotin, and $0.16 \mathrm{mg}$ thiamine (per liter), to give a final $\mathrm{OD}_{600}$ of $60.40 \mathrm{ml}$ of $24 \mathrm{~g} / \mathrm{l}$ soluble starch, which was sterilized by autoclaving, was added to Bio Jr.8 fermentor (ABLE Biott, Japan), and the temperature was set at 30,35 , or $40^{\circ} \mathrm{C}$. After the temperature had stabilized, $40 \mathrm{ml}$ of the cell suspension was added to the bioreactor, resulting in a $80 \mathrm{ml}$ culture with an $\mathrm{OD}_{600}$ of 30 and a final concentration of $12 \mathrm{~g} / \mathrm{l}$ soluble starch. For repeated reactions, a $45 \mathrm{~g} / \mathrm{l}$ soluble starch solution was used. After each reaction, cells were harvested by centrifugation $(5000 \times \mathrm{g}$, $4^{\circ} \mathrm{C}$ for $10 \mathrm{~min}$ ) and then washed once with $\mathrm{K} 10$ medium. The cell pellet was resuspended in $40 \mathrm{ml}$ of $\mathrm{K} 10$ medium, to which $40 \mathrm{ml}$ of $90 \mathrm{~g} / \mathrm{l}$ soluble starch solution was added, giving $80 \mathrm{ml}$ cell suspensions containing $45 \mathrm{~g} / \mathrm{l}$ soluble starch. Cell suspensions were agitated at $120 \mathrm{rpm}$ without aeration. Anaerobic conditions were achieved by the rapid consumption of residual oxygen in the medium by cells. The $\mathrm{pH}$ of the medium was maintained at 7.0 throughout the reaction using a $5.0 \mathrm{~N}$ ammonia solution.

\section{Analytical procedures}

$\mathrm{OD}_{600}$ was measured using a spectrophotometer (UVmini1240; Shimadzu, Japan). Organic acids (lactate, succinate, and acetate) were quantified in centrifuged samples $\left(15,000 \mathrm{rpm}, 4^{\circ} \mathrm{C}, 10 \mathrm{~min}\right)$ using a high-performance liquid chromatograph (Shimadzu) equipped with a UV/VIS detector (SPD-20A) and a BioRad Aminex 87H column (BioRad Laboratories, USA) operating at $50^{\circ} \mathrm{C}$ with a $5 \mathrm{mM}$ $\mathrm{H}_{2} \mathrm{SO}_{4}$ mobile phase at a flow rate of $0.6 \mathrm{ml} / \mathrm{min}$. The starch concentration was measured using an EnzyChrom Starch Assay Kit (Funakoshi) according to the manufacturer's instructions.

\section{a-Amylase activity measurement}

$\alpha$-Amylase activity was measured with an $\alpha$-amylase measurement kit (Kikkoman, Tokyo, Japan) as described previously (Tateno et al. 2007a). An $\mathrm{OD}_{600}$ of 1.0 corresponded to $0.39 \mathrm{mg}$ dry weight cells $\mathrm{ml}^{-1}$.

\section{Results}

PgsA-anchored $a$-amylase sufficiently fermented soluble starch in high-cell density cultures of $C$. glutamicum cells A C. glutamicum strain displaying PgsA-anchored $\alpha-$ amylase was previously shown to efficiently produce lysine from starch by direct simultaneous saccharification and fermentation under aerobic growing conditions (Tateno et al. 2007a). Here, we investigated if this system could be applied for the production of organic acids using high cell-density cultures of C. glutamicum cells under anaerobic conditions. We considered that the cell-surface display of $\alpha$-amylase, as opposed to secretion, was ideal for the system because cells could be reutilized multiple times with high-cell density conditions. We fused the $\alpha$-amylase-encoding amy $A$ gene from Streptococcus bovis 148 with the C-terminal region of pgsA from Bacillus subtilis in pCC vector downstream of the $\operatorname{csp} B$ promoter, and then introduced the constructed vector (pCC-pgsA-amyA) into a wild-type C. glutamicum ATCC13032 strain. Wild-type C. glutamicum produces mainly lactate $(1.79 \mathrm{~mol} / \mathrm{mol}$ glucose $)$ and smaller amounts of succinate $(0.09 \mathrm{~mol} / \mathrm{mol}$ glucose $)$ and acetate $(0.01 \mathrm{~mol} /$ mol glucose) under anaerobic conditions (Okino et al. 2005).

The recombinant strain expressing PgsA-anchored $\alpha$-amylase on the cell surface was used for the bioproduction of organic acids directly from starch in a jar fermentor. The wild-type strain harboring pCC-pgsA was used as control. The $\mathrm{pH}$ and temperature of the jar fermentor were set at 7.0 and $30^{\circ} \mathrm{C}$, respectively. The AmyA-displaying strain degraded starch and produced organic acids, including lactate, succinate, and acetate, at a relatively constant rate over the $10 \mathrm{~h}$ culture period (Figure 1). After $10 \mathrm{~h}$ of culture, the recombinant strain produced $6.0 \pm 0.3 \mathrm{~g} / \mathrm{l}$ lactate, $1.5 \pm 0.2 \mathrm{~g} / \mathrm{l}$ succinate, and $0.7 \pm 0.1 \mathrm{~g} / \mathrm{l}$ acetate (Table 2). The control strain also produced organic acids, albeit in smaller amounts, with concentrations of $0.2 \pm 0.2 \mathrm{~g} / \mathrm{l}$ lactate, $0.3 \pm 0.1 \mathrm{~g} / \mathrm{l}$ succinate, and $0.5 \pm 0.1 \mathrm{~g} / \mathrm{l}$ acetate detected after $10 \mathrm{~h}$ (Table 2). It is likely that these organic acids were generated by the control strain from the glucose formed during the heat sterilization of starch. Although the concentration of lactate in the control reactor reached as high as $0.6 \pm$ $0.3 \mathrm{~g} / \mathrm{l}$ after $4 \mathrm{~h}$, the concentration decreased to $0.2 \pm$ $0.2 \mathrm{~g} / \mathrm{l}$ after $10 \mathrm{~h}$ indicating that the lactate was utilized as carbon source after the exhaustion of glucose due to the reversible catalytic activity of lactate dehydrogenase (LDH) (Figure 1A).

The AmyA-displaying strain mainly produced lactate (73\% of total organic acids after $10 \mathrm{~h}$ ), whereas the control strain predominantly generated acetate ( $45 \%$ of total organic acids after $10 \mathrm{~h}$ ). Glucose remained below the limit of detection (data not shown) in the culture medium of the AmyA-displaying strain after $2 \mathrm{~h}$, indicating that the glucose formed from starch by $\alpha$-amylase was immediately 

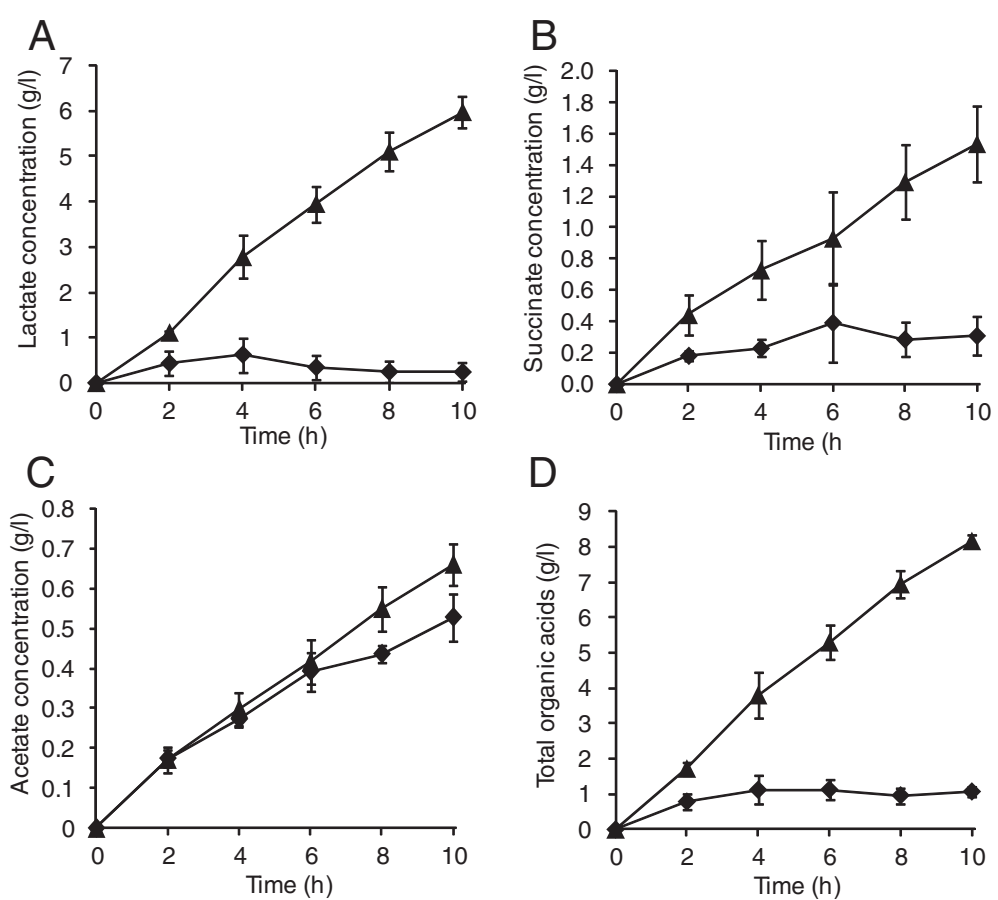

$\mathrm{D}$

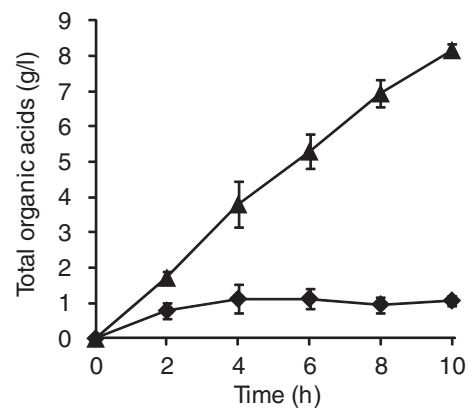

Figure 1 Production of lactate (A), succinate (B), acetate (C), and total organic acids (D) from starch by C. glutamicum ATCC13032/ pCC-pgsA-amyA (triangles) and ATCC13032/pCC-pgsA (diamonds). Data points represent the averages calculated from three independent experiments. Standard deviations are indicated by bars or are within each symbol.

transported into cells through the phosphoenolpyruvate: carbohydrate phosphotransferase system (Tanaka et al. 2008). The $\alpha$-amylase activity in the AmyA-displaying strain was $10.4 \pm 1.0$ (U/g dry weight cell) at $0 \mathrm{~h}$, but was only $0.1 \pm 0.06$ (U/g dry weight cell) in the control strain (Table 2). After $10 \mathrm{~h}$ of culture, the AmyA-displaying strain had retained its $\alpha$-amylase activity, which was $9.5 \pm$ 0.5 (U/g dry weight cell).

Effects of temperature on starch degradation and organic acid production

The above-described bioprocess experiment was conducted at $30^{\circ} \mathrm{C}$, which is the optimal growth temperature of $C$. glutamicum. However, because the optimum temperature for S. bovis AmyA activity is $50^{\circ} \mathrm{C}$ in vitro (Satoh et al. 1993), we also examined the effect of high temperature
( 35 and $40^{\circ} \mathrm{C}$ ) on organic acid production by the recombinant strain from starch. In addition, performing fermentations at high temperature would reduce production costs associated with cooling the reactor, as the metabolic activities of microorganisms typically generate heat (AbdelBanat et al. 2010).

High-density cell suspensions, which had an $\mathrm{OD}_{600}$ of 30 and a total volume of $80 \mathrm{ml}$, were cultured at 35 and $40^{\circ} \mathrm{C}$ under anaerobic conditions. Under these conditions, starch was efficiently degraded by the AmyA-displaying strain and organic acids were produced. Starch consumption was highest $(12.8 \mathrm{~g} / \mathrm{l})$ at $35^{\circ} \mathrm{C}$ after $10 \mathrm{~h}$, representing a $39 \%$ increase compared to that consumed at $30^{\circ} \mathrm{C}$ (Table 2). Interestingly, a similar amount of starch was degraded at $40^{\circ} \mathrm{C}$, even though the cells barely grew at this temperature. Glucose was not detected at either of the higher temperatures,

Table 2 Summary of organic acid production from starch at various temperatures

\begin{tabular}{|c|c|c|c|c|c|c|c|c|c|}
\hline \multirow[t]{2}{*}{ Strain } & \multirow[t]{2}{*}{$\begin{array}{c}\text { Temperature } \\
\left({ }^{\circ} \mathrm{C}\right)\end{array}$} & \multirow{2}{*}{$\begin{array}{c}\text { Starch } \\
\text { consumed } \\
(\mathrm{g} / \mathrm{l})\end{array}$} & \multicolumn{2}{|c|}{$\begin{array}{l}\text { a-Amylase activity } \\
\text { (U/g dry weight cell) }\end{array}$} & \multicolumn{4}{|c|}{ Concentration $(g / l)$} & \multirow[t]{2}{*}{ Yield $^{a}$} \\
\hline & & & $\mathrm{Oh}$ & $10 \mathrm{~h}$ & Lactate & Succinate & Acetate & Total organic acids & \\
\hline ATCC13032/pCC-pgsA & 30 & $0.2 \pm 0.2$ & $0.1 \pm 0.06$ & $0.3 \pm 0.05$ & $0.2 \pm 0.2$ & $0.3 \pm 0.1$ & $0.5 \pm 0.1$ & $1.1 \pm 0.1$ & - \\
\hline ATCC13032/pCC-pgsA-amyA & 30 & $9.2 \pm 0.2$ & $10.4 \pm 1.0$ & $9.5 \pm 0.5$ & $6.0 \pm 0.3$ & $1.5 \pm 0.2$ & $0.7 \pm 0.1$ & $8.2 \pm 0.2$ & $0.88 \pm 0.01$ \\
\hline ATCC13032/pCC-pgsA-amyA & 35 & $12.8 \pm 2.3$ & $9.9 \pm 1.0$ & $3.9 \pm 1.9$ & $7.7 \pm 0.5$ & $2.1 \pm 0.2$ & $1.0 \pm 0.1$ & $10.8 \pm 0.2$ & $0.86 \pm 0.13$ \\
\hline ATCC13032/pCC-pgsA-amyA & 40 & $12.0 \pm 2.1$ & $9.3 \pm 0.1$ & $1.4 \pm 0.7$ & $7.3 \pm 1.2$ & $1.5 \pm 0.3$ & $0.9 \pm 0.1$ & $9.7 \pm 0.7$ & $0.83 \pm 0.13$ \\
\hline
\end{tabular}

${ }^{a}$ Yield is expressed as gram of total organic acids produced per gram of sugar consumed. 
indicating it was immediately imported into cells and consumed after the degradation of starch. The total amount of produced organic acids was $32 \%$ and $18 \%$ higher at 35 and $40^{\circ} \mathrm{C}$, respectively, than at $30^{\circ} \mathrm{C}$ (Table 2 ). In addition, the ratio of produced organic acids did not markedly change depending on the reaction temperature. Notably, however, $\alpha$-amylase activity on the cell surface decreased by $61 \%$ after $10 \mathrm{~h}$ at $35^{\circ} \mathrm{C}$, whereas a decrease of only $8 \%$ was observed at $30^{\circ} \mathrm{C}$ (Table 2). AmyA-displaying cells cultured at $40^{\circ} \mathrm{C}$ exhibited an even higher decrease (85\%) of $\alpha$-amylase activity. These results indicated that AmyA proteins were stably anchored on the cell surface at $30^{\circ} \mathrm{C}$, whereas most anchored AmyA proteins were released into the medium at 35 and $40^{\circ} \mathrm{C}$. The results also showed that although AmyA proteins were not anchored on the cell surface at 35 or $40^{\circ} \mathrm{C}$, the metabolic activity of C. glutamicum cells was maintained.

\section{Repeated production of organic acids from starch}

Cell-surface engineering is an ideal technology for the repeated use of cells, but only if the displayed protein maintained activity after several culture cycles and associated centrifugation steps, and medium exchange. Here, the ability of cell-surface engineered C. glutamicum cells to produce organic acids in repeated culture cycles was therefore investigated.

Cell suspensions of ATCC13032/pCC-pgsA-amyA strain with an $\mathrm{OD}_{600}$ of 159 were used for the production of organic acids from $50 \mathrm{~g} / \mathrm{l}$ soluble starch as the sole carbon source in the first $10 \mathrm{~h}$ cycle. The temperature was set at $30^{\circ} \mathrm{C}$ for all cycles based on the stable $\alpha$-amylase activity observed in the initial experiments. After the completion of the first cycle, $33.2 \mathrm{~g} / \mathrm{l}$ organic acids $(27.6 \mathrm{~g} / \mathrm{l}$ lactate, $3.9 \mathrm{~g} / \mathrm{l}$ succinate, and $1.3 \mathrm{~g} / \mathrm{l}$ acetate) were produced from $39.5 \mathrm{~g} / \mathrm{l}$ starch (Table 3 ). The reaction mixture was then centrifuged and the collected cells were washed once with K10 medium. Cells were then resuspended in a total of $80 \mathrm{ml} \mathrm{K10}$ medium supplemented with $45 \mathrm{~g} / \mathrm{l}$ soluble starch. The repeated bioproduction of organic acids by the recombinant strain was performed for an additional four cycles. The initial $\mathrm{OD}_{600}$ of the cultures gradually decreased with increasing cycle number due to cell death and loss during the washing and centrifugation steps. However, the ratio of starch consumption per total cell mass between the first and last cycles was 1 to 0.77 , showing that major of the displayed $\alpha$-amylase retained activity after $50 \mathrm{~h}$. During the total $50 \mathrm{~h}$ culture period, with consisted of five cycles in the bioreactor, $128.5 \mathrm{~g} / \mathrm{l}$ starch was consumed and $107.8 \mathrm{~g} / \mathrm{l}$ organic acids were produced, including $88.9 \mathrm{~g} / \mathrm{l}$ lactate and $14.0 \mathrm{~g} / \mathrm{l}$ succinate with the yield of $0.84 \mathrm{~g} / \mathrm{g}$ (Table 3 ).

\section{Discussion}

In the present study, we demonstrated the applicability of cell surface-engineering technology in C. glutamicum for production of the organic acids lactate and succinate from high-density cultures under anaerobic conditions. Although the Streptococcus bovis 148 AmyA protein used in this study has optimal in-vitro activity at $50^{\circ} \mathrm{C}$, we demonstrated that the in vivo production of organic acids from starch could be achieved at 35 or $40^{\circ} \mathrm{C}$, which is markedly higher than the optimal growth temperature of $30^{\circ} \mathrm{C}$ for C. glutamicum. At these temperatures, the consumption of starch and production of organic acids were accelerated with increasing reaction temperature. In a previous study examining lysine production from starch by C. glutamicum cells expressing PgsA-anchored $\alpha$-amylase, cultivation at $40^{\circ} \mathrm{C}$ resulted in severe growth defects that were accompanied by dramatic decreases in lysine production and starch consumption compared to those observed at 30,34 , and $37^{\circ} \mathrm{C}$ (Tateno et al. 2007a). This difference was apparently because lysine production was performed under growing conditions. In contrast, the resting-cell reactions performed here with high celldensity cultures of C. glutamicum maintained their metabolic capacity despite the apparent lack of cell growth at higher temperature, and showed even higher starch consumption and organic acid production. Therefore, the optimal temperatures for cell growth and the central metabolic pathway that converts glucose to lactic acid, succinic acid, and acetic acid are likely different. However, because the ratio of produced organic acids did not alter dramatically at different temperatures, the optimal temperature for enzymes in the central metabolic pathway

Table 3 Production of organic acids from starch by C. glutamicum cells in repeated cycles

\begin{tabular}{|c|c|c|c|c|c|c|c|c|c|}
\hline \multirow[t]{2}{*}{ Cycle } & \multirow{2}{*}{$\begin{array}{l}\text { Start } \\
O D_{600}\end{array}$} & \multirow{2}{*}{$\begin{array}{l}\text { Consumed } \\
\text { starch }(g / l)\end{array}$} & \multicolumn{2}{|c|}{ a-Amylase activity (U/g dry weight cell) } & \multicolumn{4}{|c|}{ Concentration $(g / l)$} & \multirow[t]{2}{*}{ Yield $^{\mathrm{C}}$} \\
\hline & & & $\mathrm{Oh}$ & $10 \mathrm{~h}$ & Lactate & Succinate & Acetate & Total organic acids & \\
\hline 1 & 159 & 39.5 & 15.4 & 9.4 & 27.6 & 3.9 & 1.3 & 32.8 & 0.83 \\
\hline 2 & 122 & 27.5 & 9.5 & 7.2 & 19.5 & 2.8 & 0.8 & 23.2 & 0.84 \\
\hline 3 & 103 & 23.0 & 7.0 & 5.4 & 15.6 & 2.4 & 0.9 & 18.9 & 0.82 \\
\hline 4 & 99 & 21.2 & 7.8 & 5.4 & 14.4 & 2.7 & 1.1 & 18.3 & 0.86 \\
\hline 5 & 91 & 17.3 & 6.8 & 5.0 & 11.8 & 2.2 & 0.8 & 14.8 & 0.86 \\
\hline
\end{tabular}

${ }^{a}$ Yield is expressed as gram of total organic acids produced per gram of sugar consumed.

Each cycle was performed for $10 \mathrm{~h}$ at $30^{\circ} \mathrm{C}$. 
of C. glutamicum is likely to be similar. In resting cells of Brevundimonas diminuta, the production of ascorbic acid-2-phosphate was enhanced at $40^{\circ} \mathrm{C}$ compared to the optimal growth temperature of $30^{\circ} \mathrm{C}$ (Shin et al. 2007). Production of chemicals and fuels at higher temperature is advantageous for industrial processes, because it would reduce the risk of contamination during fermentation. More directly, higher temperatures would reduce the costs for cooling of the reactor. For example, a $5^{\circ} \mathrm{C}$ increase in the fermentation temperature would reportedly save approximately $\$ 30,000$ per year for a $30 \mathrm{~m}^{3}$ scale plant (AbdelBanat et al. 2010).

The AmyA protein fused with the C-terminus of cellsurface protein PgsA remained stable anchoring to the cell surface after several reaction cycles at $30^{\circ} \mathrm{C}$, which included cell washing and medium exchange events. This finding contrasted that of the previous study on lysine production showing that cell-surface expressed AmyA protein was released into the medium at $30^{\circ} \mathrm{C}$. There are two possible explanations for this difference. First, a certain proportion of fusion $\alpha$-amylase proteins may be firmly anchored on the cell surface, whereas other fusion proteins failed to anchor after being transported to the cell surface. The second possibility is that stable anchoring of the fusion protein might be dependent on cell division, as we observed that organic acid production occurred in the absence of apparent cell growth. In either case, screen of more stable anchoring proteins would be desired to display $\alpha$-amylase, or other protein of interest, on the cell surface of C. glutamicum cells. More stable anchoring proteins could lead to enhance process productivity at high temperature with repeated use of C. glutamicum cells, that could not be obtained by protein secretion.

In conclusion, we demonstrated that cell surfaceengineering technology was advantageous for the repeated use of C. glutamicum cells cultured at high cell-density for organic acid production. This approach could be applied for displaying other biomass-degrading enzymes for the direct production of organic acids from renewable biomass.

\section{Competing interests}

The authors declare that they have no competing interests

\section{Authors' contributions}

YT performed bioprocess reaction, enzyme assay and wrote the manuscript. TTateno designed and constructed plasmids and strains. KS performed HPLC analysis. TH and TTanaka critically revised the manuscript. AK supervised on the manuscript. All authors read and approved the final manuscript.

\section{Acknowledegments}

This work was supported in part by the commission for Development of Artificial Gene Synthesis Technology for Creating Innovative Biomaterial from the Ministry of Economy, Trade and Industry (METI), Japan. This work was also supported in part by Special Coordination Funds for promoting Science and Technology, Creation of Innovation Centers for Advanced Interdisciplinary Research Areas (Innovative Bioproduction, Kobe), Japan.

\section{Author details}

'Organization of Advanced Science and Technology, Kobe University, 1-1 Rokkodai, Nada, Kobe 657-8501, Japan. ${ }^{2}$ Department of Chemical Science and Engineering, Graduate School of Engineering, Kobe University, 1-1 Rokkodai, Nada, Kobe 657-8501, Japan. ${ }^{3}$ Biomass Engineering Program, RIKEN, 1-7-22 Suehiro-cho, Tsurumi-ku, Yokohama, Kanagawa 230-0045, Japan. ${ }^{4}$ Department of Food Bioscience and Technology, College of Life Sciences and Biotechnology, Korea University, Seoul 136-713, Republic of Korea.

Received: 7 October 2013 Accepted: 12 December 2013

Published: 17 December 2013

\section{References}

Abdel-Banat BM, Hoshida H, Ano A, Nonklang S, Akada R (2010) Hightemperature fermentation: how can processes for ethanol production at high temperatures become superior to the traditional process using mesophilic yeast? Appl Microbiol Biotechnol 85:861-867

Adachi N, Takahashi C, Ono-Murota N, Yamaguchi R, Tanaka T, Kondo A (2013) Direct L-lysine production from cellobiose by Corynebacterium glutamicum displaying beta-glucosidase on its cell surface. Appl Microbiol Biotechnol 97:7165-7172

Inui M, Murakami S, Okino S, Kawaguchi H, Vertès AA, Yukawa H (2004) Metabolic analysis of Conynebacterium glutamicum during lactate and succinate productions under oxygen deprivation conditions. J Mol Microbiol Biotechnol 7:182-196

Katahira S, Fujita Y, Mizuike A, Fukuda H, Kondo A (2004) Construction of a xylanfermenting yeast strain through codisplay of xylanolytic enzymes on the surface of xylose-utilizing Saccharomyces cerevisiae cells. Appl Environ Microbiol 70:5407-5414

Kinoshita S (1985) Glutamic acid bacteria. In: Demain AL, Solomon NA (eds) Biology of industrial microorganisms. Cummings, London, pp 115-146

Kuroda K, Ueda M (2010) Engineering of microorganisms towards recovery of rare metal ions. Appl Microbiol Biotechnol 87:53-60

Kuroda K, Ueda M (2011) Cell surface engineering of yeast for applications in white biotechnology. Biotechnol Lett 33:1-9

Litsanov B, Brocker M, Bott M (2012) Toward homosuccinate fermentation: metabolic engineering of Corynebacterium glutamicum for anaerobic production of succinate from glucose and formate. Appl Environ Microbiol 78:3325-3337

Matano Y, Hasunuma T, Kondo A (2012) Display of cellulases on the cell surface of Saccharomyces cerevisiae for high yield ethanol production from high-solid lignocellulosic biomass. Bioresource Technol 108:128-133

Matano Y, Hasunuma T, Kondo A (2013) Cell recycle batch fermentation of highsolid lignocellulose using a recombinant cellulase-displaying yeast strain for high yield ethanol production in consolidated bioprocessing. Bioresource Technol 135:403-409

Murai T, Ueda M, Yamamura M, Atomi H, Shibasaki Y, Kamasawa N, Osumi M, Amachi T, Tanaka A (1997) Construction of a starch-utilizing yeast by cell surface engineering. Appl Environ Microbiol 63:1362-1366

Nakayama K, Kitada S, Kinoshita S (1961) Studies on lysine fermentation I. The control mechanism on lysine accumulation by homoserine and threonine. J Gen Appl Microbiol 7:145-154

Narita J, Okano K, Kitao T, Ishida S, Sewaki T, Sung MH, Fukuda H, Kondo A (2006) Display of alpha-amylase on the surface of Lactobacillus casei cells by use of the PgsA anchor protein, and production of lactic acid from starch. Appl Environ Microbiol 72:269-275

Okino S, Inui M, Yukawa H (2005) Production of organic acids by Corynebacterium glutamicum under oxygen deprivation. Appl Microbiol Biotechnol 68:475-480

Okino S, Noburyu R, Suda M, Jojima T, Inui M, Yukawa H (2008a) An efficient succinic acid production process in a metabolically engineered Corynebacterium glutamicum strain. Appl Microbiol Biotechnol 81:459-464

Okino S, Suda M, Fujikura K, Inui M, Yukawa H (2008b) Production of D-lactic acid by Corynebacterium glutamicum under oxygen deprivation. Appl Microbiol Biotechnol 78:449-454

Sambrook J, Fritsh E, Maniatis T (1989) Molecular cloning: a laboratory manual. Cold Spring Harbor Laboratory Press, Cold Spring Harbor, NY

Satoh E, Niimura Y, Uchimura T, Kozaki M, Komagata K (1993) Molecular cloning and expression of two a-amylase genes from Streptococcus bovis 148 in Escherichia coli. Appl Environ Microbiol 63:4941-4944 
Shin WJ, Kim BY, Bang WG (2007) Optimization of ascorbic acid-2-phosphate production from ascorbic acid using resting cell of Brevundimonas diminuta. J Microbiol Biotechnol 17:769-773

Tanaka Y, Okai N, Teramoto H, Inui M, Yukawa H (2008) Regulation of the expression of phosphoenolpyruvate: carbohydrate phosphotransferase system (PTS) genes in Corynebacterium glutamicum R. Microbiology 154:264-274

Tateno T, Fukuda H, Kondo K (2007a) Production of L-Lysine from starch by Corynebacterium glutamicum displaying a-amylase on its cell surface. Appl Microbiol Biotechnol 74:1213-1220

Tateno T, Fukuda H, Kondo A (2007b) Direct production of L-lysine from raw corn starch by Corynebacterium glutamicum secreting Streptococcus bovis alphaamylase using cspB promoter and signal sequence. Appl Microbiol Biotechnol 77:533-541

Tsuge Y, Yamamoto S, Kato N, Inui M, Yukawa H (2013) Reactions upstream of glycerate-1,3-bisphosphate drive Corynebacterium glutamicum D-lactate productivity under oxygen deprivation. Appl Microbiol Biotechnol 97:6693-6703

Werpy T, Petersen G (2004) Top value added chemicals from biomass. Volume 1: results of screening for potential candidates from sugars and synthesis gas. U.S. Department of Energy, Oak Ridge, TN, USA, p 76

Yamada R, Nakatani Y, Ogino C, Kondo A (2013) Efficient direct ethanol production from cellulose by cellulase- and cellodextrin transporter-coexpressing Saccharomyces cerevisiae. AMB Express 24(3):34

Yamakawa S, Yamada R, Tanaka T, Ogino C, Kondo A (2012) Repeated fermentation from raw starch using Saccharomyces cerevisiae displaying both glucoamylase and a-amylase. Enzyme Microb Technol 50:343-347

doi:10.1186/2191-0855-3-72

Cite this article as: Tsuge et al: Direct production of organic acids from starch by cell surface-engineered Corynebacterium glutamicum in anaerobic conditions. AMB Express 2013 3:72.

\section{Submit your manuscript to a SpringerOpen ${ }^{\circ}$ journal and benefit from:}

- Convenient online submission

- Rigorous peer review

- Immediate publication on acceptance

- Open access: articles freely available online

- High visibility within the field

- Retaining the copyright to your article

Submit your next manuscript at $\gg$ springeropen.com 